\title{
KINERJA RANTAI PASOK SAYURAN DENGAN PENDEKATAN SCOR (STUDI KASUS: PONDOK PESANTREN AL-ITTIFAQ DI KABUPATEN BANDUNG)
}

\author{
Dwi Putriana N. Kinding', Wahyu Budi Priatna ${ }^{2}$ dan Lukman M. Baga ${ }^{3}$ \\ 1) Mahasiswa Program Magister Sains Agribisnis, Sekolah Pascasarjana, Institut Pertanian Bogor \\ 2,3) Departemen Agribisnis, Fakultas Ekonomi dan Manajemen, Institut Pertanian Bogor \\ e-mail : 1) dwi.putriana94@gmail.com \\ (Diterima 9 Mei 2019/Disetujui 31 Mei 2019)
}

\begin{abstract}
Knowing the performance of a company is needed in order to be able to determine the extent to which goals have been achieved. The final objective of this research was to analyze the performance of Al-Ittifaq vegetable supply chain for each of its members in order to achieve a common goal, by maximizing the resources they have with their best practices. The analytical method used in this research was the Supply Chain Operational Reference (SCOR) model by considering the internal and external attributes of the foodSCOR card. The four attributes used in this study were reliability, responsiveness, agility, and assets. The results of measuring internal performance in the supply chain at all levels in the responsiveness and agility attributes had achieved superior performance positions on the foods card. The value of Al-Ittifaq vegetable supply chain performance on reliability attributes in conformity performance with the standards was still in the advantage position, while the delivery performance and order fulfillment were already in a superior position. The internal performance of the Al-Ittifaq vegetable supply chain in each section for the cash to cash cycle time attribute had reached a superior position. The daily inventory performance was still in the advantage position, therefore Al-Ittifaq it still needs improvement in performance by not doing a daily inventory to reduce storage costs and to always provide fresh vegetables.
\end{abstract}

Keywords: performance, SCOR, supply chain, vegetables

\begin{abstract}
ABSTRAK
Mengetahui kinerja suatu perusahaan sangat dibutuhkan, untuk mengetahui sejauh mana tujuan sudah tercapai. Tujuan akhir pada penelitian ini yaitu untuk menganalisis kinerja rantai pasok sayuran Al-Ittifaq pada setiap anggotanya guna mencapai tujuan bersama, dengan memaksimalkan sumber daya yang dimiliki dengan praktik terbaiknya. Metode analisis yang digunakan adalah model Supply Chain Operational Reference (SCOR) dengan mempertimbangkan atribut internal dan eksternal dari foodSCOR card. Empat atribut yang digunakan dalam penelitian kali ini adalah reliability, responsiveness, agility dan asset. Hasil pengukuran kinerja internal pada rantai pasok di semua tingkatan pada atribut responsiveness dan agility telah mencapai posisi kinerja superior pada foodCSOR card. Nilai kinerja rantai pasok sayuran Al-Ittifaq pada atribut reliabiliy pada kinerja kesesuaian kesesuaian dengan standar masih pada posisi advantage, sedangkan pada kinerja pengiriman dan pemenuhan pesanan sudah berada poda posisi superior. Kinerja internal rantai pasok sayuran Al-Ittifaq pada setiap bagian untuk atribut cash to cash cycle time sudah mencapai posisi superior. Nilai kinerja persediaan harian masih pada posisi advantage, sehingga Al-Ittifaq masih membutuhkan perbaikan kinerja dengan tidak melakukan persediaan harian untuk mengurangi biaya penyimpanan dan agar selalu menghadirkan sayuran segar.
\end{abstract}

Kata Kunci: kinerja, rantai pasok, sayuran, SCOR 


\section{PENDAHULUAN}

Sayuran merupakan komoditas hortikultura yang memiliki peran penting dalam keseimbangan pangan, sehingga perlu ketersediaanya setiap hari dalam jumlah yang cukup, serta mudah diperoleh dan memiliki kualitas yang baik sebagai sumber gizi tubuh. Banyaknya manfaat bagi tubuh, sayuran juga memiliki nilai ekonomis yang cukup tinggi. Kegiatan usaha agribisnis hortikultura ini sebagai sumber pemenuhan kebutuhan peningkatan ekonomi bagi masyarakat, selain untuk pemenuh kebutuhan swasembada pangan (Direktorat Jenderal Hortikultura 2010).

Undang-Undang Nomor 13 tahun 2010 tentang hortikultura, telah memberikan payung hukum terhadap penyelenggaraan pembangunan hortikultura. Secara intensif menjadikan dapat tercapainya sasaran produksi, produktivitas, mutu, serta daya saing sesuai dengan target yang diinginkan. Selaras dengan Rencana Strategis Direktorat Jenderal Hortikultura tahun 2015 sampai tahun 2019, menunjukkan bahwa hortikultura merupakan salah satu subsektor yang menjadi unggulan sumber devisa negara. Dibuktikan dengan data data BPS (2017), PDB subsektor hortikultura atas harga dasar berlaku pada tahun 2017 mencapai Rp 196.132 miliar meningkat dengan laju pertumbuhan sebesar 4,66 persen, apabila dibandingkan dengan tahun 2016 sebesar Rp 187.403 miliar. Sub sektor hortikultura mampu memenuhi kebutuhan hidup petani dan usaha pertaniannya (Direktorat Jenderal Hortikultur 2017).

Upaya ini tidak mudah untuk dilakukan dikarenakan berbagai tantangan dan permasalahan yang dihadapi. Tantangan tersebut mencakup perubahan iklim, peningkatan jumlah penduduk, distribusi yang belum merata, semakin sempitnya lahan pertanian, tingginya laju urbanisasi, perekonomian global yang melemah, gejolak harga serta ketidak pastian harga pangan khususnya komoditas hortikultura. Permasalahan yang dihadapi meliputi aspek lahan, infrastruktur, sarana produksi, regulasi/ kelembagaan, sumberdaya manusia, dan permodalan (Direktorat Jenderal Hortikultur 2017).

Tabel 1. Perkembangan jumlah produksi, luas panen dan produktivitas sayuran di Indonesia Tahun 2012 $-2016$

\begin{tabular}{|c|c|c|c|}
\hline Tahun & $\begin{array}{c}\text { Luas } \\
\text { Panen (ha) }\end{array}$ & Produksi & Produktivitas \\
\hline 2012 & 46.992 & 489.214 & 16,6 \\
2013 & 47.648 & 503.157 & 15,3 \\
2014 & 48.769 & 519.857 & 14,9 \\
2015 & 45.616 & 508.788 & 15,4 \\
2016 & 45.953 & 539.382 & 15,8 \\
\hline
\end{tabular}

Sumber: Badan Pusat Statistik dan Direktorat Jenderal Hortikultura (2017)

Tabel 1 menerangkan perkembangan budidaya sayuran di Indonesia mengalami peningkatan dari tahun ke tahun, ditandai dengan meningkatnya luas lahan yang berdampak pada total produksi yang meningkat pula. Tahun 2016 luas panen meningkat dari tahun 2015, peningkatan luas panen ini menjadikan adanya peningkatan produksi yang besar dari tahun sebelumnya dikarenakan produktivitasnya yang meningkat dibanding tahun sebelumnya (BPS 2017). Hal ini menandakan bahwa para pelaku usaha dan pemerintah semakin mengembangkan sektor hortikultura.

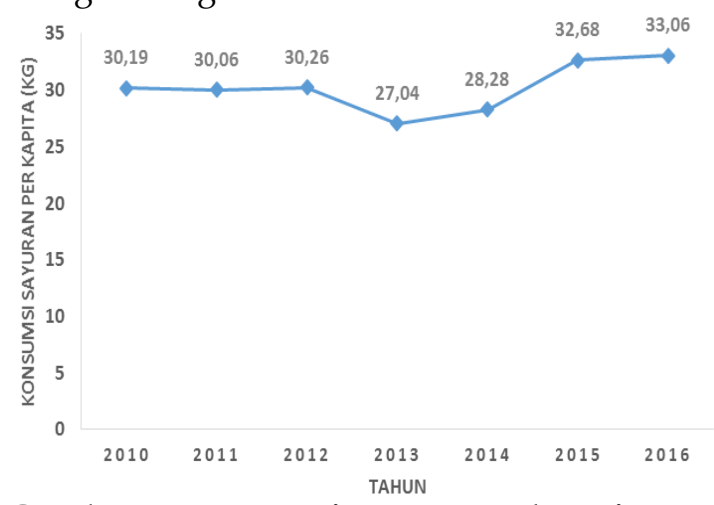

Gambar 1. Konsumsi sayuran Indonesia per kapita $(\mathrm{Kg})$

Sumber: Kementan (2017) 
Gambar 1 menerangkan mengenai data konsumsi sayuran pada masyarakat Indonesia. Terlihat bahwa konsumsi sayuran pada tahun 2010 sebesar 30,19 $\mathrm{kg} / \mathrm{kapita} /$ tahun terjadi peningkatan pada tahun 2016 menjadi sebesar 33,06 $\mathrm{kg} / \mathrm{kapita} /$ tahun. Menandakan pola konsumsi masyarakat yang berubah terhadap pertimbangan kebutuhan gizi tubuhnya (Kementan 2017). Meningkatnya pendapatan dan kesejahteraan masyarakat saat ini, menyebabkan adanya pergeseran pola konsumsi dan gaya hidup ke arah yang lebih baik. Pergeseran tersebut meningkatkan permintaan terhadap sayuran dengan kualitas dan kuantitas yang lebih baik.

Karakteristik sayuran yang hanya dapat tumbuh dengan baik di suatu daerah spesifik, menjadikan setiap daerah mempunyai keunggulan masing-masing. Tidak semua daerah memiliki potensi yang sama untuk dapat menanam semua jenis sayuran, maka diperlukan pemenuhan kebutuhan pasokan sayuran dari daerah lain. Jawa Barat memiliki potensi keunggulan dalam karakteristik budidaya komoditas sayuran di kawasan budidaya dataran tinggi dan dataran rendah. Menjadikan Provinsi Jawa Barat sebagai salah satu daerah sentral sayuran di Indonesia dengan jumlah produksi sebanyak 21.152.712 kwintal ratarata produksi pada tahun 2016 (BPS 2017).

Salah satu pelaku usaha agribisnis hortikultur khusunya komoditas sayuran adalah Pondok Pesantren Al-Ittifaq. Tidak hanya sebagai lembaga pendidikan agama, melainkan mengajarkan berbagai kegiatan di bidang pertanian juga kepada para santrinya. Pergeseran lembaga pendidikan pondok pesantren menuju orientasi kemandirian ekonomi tau kewirausahaan yang diwujudkan oleh Al-Ittifaq (Polindi 2019). Terletak di daerah pegunungan dataran tinggi di Kampung Ciburial Desa Alamendah Kecamatan Rancabali Kabupaten Bandung yang memiliki suhu rendah, sehingga sangat cocok untuk melakukan budidaya sayuran dataran tinggi sebagai komoditas unggulannya, antara lain wortel, daun bawang dan seledri. Kegiatan usaha yang dilakukan tidak hanya mengusahakan lahan pertanian sendiri sebagai tempat produksi, namun mampu menampung hasil pertanian dari kelompok tani di sekitar pondok pesantren dan juga menjadi koperasi penyalur hasil budidaya santri alumni untuk dipasarkan ke konsumen ritel.

Seluruh pelaksanaan kegiatan agribisnisnya pada Al-Ittifaq melibatkan para santri, alumni dan juga menjalin kerja sama dengan berbagai pihak dengan bentuk kemitraan. Pihak dari luar Al-Ittifaq yang melakukan kerja sama antara lain dengan masyarakat petani sekitar pesantren dan perusahaan ritel. Kegiatan yang dilakukan petani mitra tidak hanya menyalurkan hasil panen kepada Al-Ittifaq, melainkan mendapatkan pembinaan dan pengetahuan peningkatkan kapasitas produksi. Peningkatan produksi baik kualitas maupun kuantitas, peningkatan pengetahuan terhadap kegiatan budidaya yang sesuai, dan peningkatan efisiensi usaha sehingga pada akhirnya pendapatan usahatani yang lebih tinggi guna menunjang kesejahteraan. Hadirnya kemitraan dengan petani sekitar Pondok Pesantren Al-Ittifaq ini diharapkan dapat meningkatkan pendapatan dan kesejahteraan. Fauroni (2011) menjelaskan, bahwa Pesantren sebagai lembaga pendidikan dan lembaga keagamaan yang telah terbukti menjadi pusat pendidikan dan menjadi barometer pertahanan moralitas umat, sehingga mampu menghadapi perubahan dan tantangan sosial masyarakat baik konteks lokal, nasional maupun global

Semakin banyaknya permintaan dari berbagai ritel membuat jaringan rantai pasok sayuran ada Al-Ittifaq ini semakin kompleks. Munculnya beberapa hambatan dalam permintaan, di mana konsumen menyukai produk dalam keadaan bersih, segar dan tersedia setiap saat. Hal tersebut berbanding terbalik dengan karaktersistik sayuran itu sendiri yang mudah rusak dan keberadaanya dipengaruhi oleh banyak faktor alam. Permasalahan selanjutnya adalah peningkatan pesanan yang tidak semuanya 
dapat dipenuhi, sehingga perusahaan membatasi beberapa permintaan dari ritel. Keputusan perusahaan ini dilakukan karena ketakutan apabila tidak terpenuhinya permintaan yang akan mengurangi performa perusahaan. Hal ini merupakan peluang sekaligus hambatan bagi perusahaan yang harus dicari solusi sebagai keputusan terbaik perusahaan, sehingga perlu adanya peninjauan dalam manajerial.

Manajemen rantai pasok dapat digunakan untuk mengkoordinir dan mengevaluasi seluruh aktivitas pada mata rantai yang terlibat. Khususnya pada ketidakpastian di setiap rantai pasok sayuran dalam menyediakan pasokan terbaiknya, agar memperbaiki dan memaksimalkan sumber daya rantai pasok sayuran yang masih terdapat permasalahan. Manajemen rantai pasok menjelaskan bentuk koordinasi dan struktur manajemen dalam jaringan yang memfasilitasi proses pengambilan keputusan secara cepat dan pelaksanaan proses oleh pelaku rantai pasok (Yolandika 2016).

Pembentukan model pengembangan agribisnis sayuran memerlukan kepastian akses pelaku rantai pasok terhadap ketersediaan sarana produksi, cara produksi, dan pemasaran yang efisien. Kemampuan bekerja sama dan integrasi antara pelaku yang terlibat, kesatuan arah dan ketepatan kebijakan dari pemegang kekuasaan juga dibutuhkan (Pujawan 2005). Sistem pengukuran kinerja sangat diperlukan rantai pasok sayuran, salah satu cara dalam mengoptimalkan jaringan rantai pasok agar berjalan sesuai tujuan utama secara efisien. Pengukuran kinerja bertujuan untuk mendukung perancangan tujuan, evaluasi kinerja, dan menentukan langkah-langkah ke depan baik pada level strategi, taktik, dan operasional (Vorst 2005).

Kendala yang dialami baik itu akses terhadap sarana produksi, kerja sama, informasi, atau hal yang tidak mendukung perkembangan rantai pasok sayuran. Pengukuran dilakukan pada seluruh anggota rantai pasok yang terlibat, untuk dilibat kontribusinya terhadap peran dan fungsi bagiannya (Apriani 2018). Pengembangan harus berdasarkan kemampuan lokal dan integrasi antar faktor, serta kesamaan tujuan dan kecepatan pelaku dalam merespon masalah pengembangan, sehingga dapat berkembang baik. Fakta-fakta tersebut dapat dianalisis untuk memberikan sebuah pandangan alternatif kondisi dan evaluasi rantai pasok untuk pengembangan strategi yang akan diterapkan sesuai dengan kebutuhan Al-Ittifaq dalam mencapai target. Tujuan penelitian adalah mengukur kinerja rantai pasok sayuran pada Pondok Pesantren Al-Ittifaq.

\section{METODE}

\section{Lokasi dan Waktu Penelitian}

Penentuan lokasi penelitian dilakukan secara sengaja (purvosive) pada Pondok Pesantren Al-Ittifaq. Hal ini berdasarkan karena perusahaan yang memiliki model unik, di mana tidak hanya berdiri sebagai lembaga pendidikan agama saja, melainkan dapat melakukan kegiatan agribisnis dari mulai pengadaan hingga penyaluran dengan konsumen berupa pasar modern yang cukup luas. Petani mitra yang diteliti terletak di daerah Ciwidey, sedangkan ritel mitra yang diteliti tersebar di area Bandung, Cimahi dan Tangerang. Penelitian dilaksanakan mulai bulan Januari hingga Februari 2019, penggunaan data pada satu musim tanam yaitu bulan Oktober sampai Desember 2018.

\section{Metode Pengumpulan Data}

Jenis data yang digunakan dalam penelitian ini adalah data primer dan data sekunder. Data primer diperoleh dari hasil observasi, wawancara mendalam dan metode dengan melakukan diskusi dengan wakilwakil perusahaan atau kelompok pada perusahaan sebagai para pelaku rantai pasok. Data sekunder diperoleh dari literatur, artikel, jurnal, penelitian terdahulu dan data yang relevan dari instansi terkait untuk mendukung data primer. 


\section{Metode Penentuan Responden}

Pemilihan semua responden pada penelitian ini dilakukan secara sengaja (purposive sampling), yaitu perusahaan (AlIttifaq), petani mitra sebanyak 12 orang dengan pertimbangan petani yang memasok sayuran secara continue kepada perusahaan (Al-Ittifaq). Pemilihan perusahaan karena perusahaan ini memiliki model yang unik. Selanjutnya responden ritel juga dipilih dengan pertimbangan ritel yang memiliki permintaan sayuran paling dominan dan continue terhadap perusahaan.

\section{Metode Analisis Data}

Penghitungan kinerja rantai pasok sayuran pada penelitian ini menggunakan atribut pada metode Supply Chain Operation Refference (SCOR). Atribut yang digunakan pada pengukuran kinerja menggunakan SCOR terdapat empat yang dibedakan menjadi kinerja internal (asset) dan kinerja eksternal (reliability, agility, dan responsiveness). Atribut kinerja menurut SCC (2008) diturunkan menjadi matrik-matrik kinerja sebagai berikut :

\section{Reliability (Kendala) merupakan} kemampuan perusahaan untuk melakukan pekerjaan sesuai dengan yang diharapkan; tepat waktu, kualitas yang sesuai dan jumlah yang tepat.

1. Kinerja pengiriman (Perfect Order Fulfillment) adalah persentase pesanan yang memenuhi kinerja pengiriman dengan utuh dan akhurat tanpa kerusakan pengiriman.

Kinerja pengiriman $=$

Total pesanan dikirim tepat waktu $\times 100 \%$ Total pesanan yang dikirim

2. Pemenuhan pesanan (Order fulfillment cycle time) adalah waktu siklus aktual ratarata yang secara konsisten diterima untuk memenuhi pesanan konsumen. Untuk setiap pesanan waktu siklus dimulai dari penerimaan pesanan dan berakhir saat konsumen menerima pesanan tersebut.

Pemenuhan pesanan $=$
Jumlah waktu semua pesanan dikirim Jumlah total pesanan yang dikirim

3. Kesesuaian dengan standar adalah persentase jumlah permintaan yang dikirimkan sesuai dengan standar yang ditentukan konsumen (persen).

Kesesuaian dengan standar $=$

Total pesanan yang sesuai standar $\times 100 \%$

Total pesanan yang dikirim

Agility (Ketangkasan) adalah waktu yang dibutuhkan rantai pasok untuk merespon ketika ada perubahan pesanan atau pesanan tidak terduga, baik ada peningkatan maupun penurunan pesanan jumlah tanpa ada biaya pinalti (hari).

Siklus pemenuhan pesanan $=$ Siklus mencari barang + Siklus pengemasan barang + Siklus mengirim barang

Responsiveness (Kemampuan reaksi) adalah kecepatan dalam melaksanakan pekerjaan, antara lain diukur menggunakan:

1. Lead Time Pemenuhan Pesanan adalah waktu rata-rata yang dibutuhkan oleh petani atau perusahaan untuk memenuhi pesanan konsumen (hari).

2. Siklus Pemenuhan Pesanan adalah waktu yang dibutuhkan untuk satu kali sikluk order/pesanan ke pemasok (hari).

Siklus pemenuhan pesanan $=$ Waktu perencana + Waktu Pengemasan + Waktu pengiriman

Asset (Manajemen Aset) adalah kemampuan untuk memanfaatkan aset secara produktif.

1. Cash to Cash Cycle Time adalah waktu antara pelaku rantai pasok membayar ke pelaku sebelumnya dan menerima pembayaran dari pelaku setelahnya (hari).

2. Persediaan harian (Inventory days of supply) adalah lamanya persediaan yang cukup untuk memenuhi kebutuhan jika tidak ada pasokan (hari).

Persediaan harian $=\underline{\text { Rata-rata persediaan }}$

Rata-rata kebutuhan

Menurut Bolstorff dan Rosenbaum (2011), setelah diukur besaran nilai matrik pada setiap indikator, kemudian dibandingkan dengan nilai dengan benchmark 
kinerja. Bencmarking yang digunakan dalam penelitian ini merupakan kombinasi penetapan oleh Supply Chain Council dan pengukuran rantai pasok pada perusahaan yang berada dalam konteks lingkungan yang kompetitif (Harrison dan Hoek 2008; Francis et al. 2008). Benchmark yang terdiri dari tiga klasifikasi nilai yaitu parity, advantages dan superior. Parity adalah klasifikasi nilai terendah, Advantages adalah klasifikasi nilai menengah sedangkan Superior adalah klasifikasi nilai tertinggi target efektivitas sebuah kinerja rantai pasok. Data pada kategori superior diperoleh dari 90 persen organisasi-organisasi dengan nilai terbaik untuk masing-masing metrik. Pengukuran dan penetapan target pencapaiannya selesai dilakukan pada rantai pasok, kemudian melakukan identifikasi untuk menetapkan praktik-praktir terbaik yang harus dilaksakan guna mencapai target tersebut (Setiawan 2011).

\section{HASIL DAN PEMBAHASAN}

Mengukur kinerja rantai pasok sangat dibutuhkan untuk mengetahui sejauh mana tujuan sudah tercapai. Setelah dilakukan pengukuran, maka diketahui permasalahan serta pada bagian mana yang harus lebih ditingkatkan sehingga mampu memberikan praktik-praktik terbaik, guna mencapai tujuan bersama dan mengembangkannya. Pengukuran kinerja rantai pasok diukur berdasarkan aliran rantai pasok sayuran, dimulai dari petani hingga perusahaan. Penelitian kinerja rantai pasok sayuran pada Pondok Pesantren Al-Ittifaq kali ini dilihat dari dua bagian tingkatan yaitu pada bagian kinerja petani mitra dan kinerja perusahaan (Al-Ittifaq). Pengukuran kinerja berdasarkan musiman, yaitu satu musim tanam (OktoberDesember 2019) sebagai waktu yang digunakan oleh petani mitra untuk budidaya ketiga komoditas sayuran unggul yaitu wortel, daun bawang dan seledri.

\section{Kinerja rantai pasok pada petani mitra}

Penelitian ini memilih responden petani mitra sebagai pemasok tiga jenis sayuran (wortel, daun bawang dan seledri).
Secara keseluruhan petani mitra responden berjumlah 12 orang. Pengukuran kinerja pada petani mitra dibagi menjadi dua yaitu kinerja petani secara individu dan kinerja petani menurut komoditasnya. Pengukuran kinerja individu petani mitra dihasilkan dari rata-rata nilai kinerja petani pada setiap atribut SCOR, dan kinerja petani menurut komoditasnya adalah pengukuran kinerja rantai pasok yang dikelompokan atas dasar masing-masing komoditas yang di usahakan.

Penggunaan pengelompokan perhitungan rantai pasok pada penelitian ini didasarkan karena karakteristik setiap komoditas yang berbeda-beda sehingga penanganan dan penentuan indikator pada kinerja rantai pasok berbeda. Sejalan dengan penelitian Yolandika (2016) dan Apriani et al. (2018),perlunya pengelompokan perhitungan berdasarkan komoditas karena setiap komoditas memiliki karakteristik dan penanganan yang berbeda-beda. Perbedaan karakteristik ini menjadikan adanya perbedaan pada penentuan indikator dalam penentuan kinerja rantai pasok. sejalan dengan penelitian Aramyam et al. (2007) menyatakan bahwa dibutuhkannya sistem pengukuran terpadu mengenai Agri-Food Supply Chain dikarenakan sayuran dan buahbuahan memiliki karakteristik yang berbeda dengan produk lainnya.

\section{Kinerja petani mitra secara individu}

Pengukuran kinerja rantai pasok petani mitra secara individu dilihat dari kinerja eksternal dengan indikator reliability, responsiveness dan agility, sedangkan untuk kinerja internal adalah indikator asset.

\section{Kinerja Eksternal}

Pengukuran indikator eksternal pada petani mitra secara individu dilihat dari perhitungan pada turunan atribut reliability (kinerja pengiriman pesanan, pemenuhan pesanan, kesesuian dengan standar), responsiveness (lead time pemenuhan pesanan, siklus pemenuhan pesanan) dan agility (fleksibiliti). Hasil pengukuran nilai rata-rata dari atribut kinerja dapat dilihat pada Tabel 2. 
Tabel 2. Nilai rata-rata kinerja rantai pasok pada petani mitra

\begin{tabular}{|c|c|c|c|c|c|}
\hline \multirow{2}{*}{ Atribut dan Indikator SCOR } & \multicolumn{3}{|c|}{ Bencmarking } & \multirow{2}{*}{ Rata-rata } & \multirow{2}{*}{ Hasil } \\
\hline & Parity & Advantage & Superior & & \\
\hline \multicolumn{6}{|c|}{ Kinerja Eksternal } \\
\hline $\begin{array}{l}\text { Reliability } \\
\text { Kinerja Pengiriman (\%) } \\
\text { Pemenuhan Pesanan (\%) } \\
\text { Kesesuaian dengan Standar (\%) }\end{array}$ & $\begin{array}{l}85.00-89.00 \\
94.00-95.00 \\
80.00-84.00\end{array}$ & $\begin{array}{l}90.00-94.00 \\
96.00-97.00 \\
85.00-89.00\end{array}$ & $\begin{array}{l}\geq 95.00 \\
\geq 98.00 \\
\geq 90.00\end{array}$ & $\begin{array}{l}95,84 \\
98,36 \\
89,80\end{array}$ & $\begin{array}{l}\text { Superior } \\
\text { Superior } \\
\text { Advantage }\end{array}$ \\
\hline $\begin{array}{l}\text { Agility } \\
\text { Fleksibilitas (hari) }\end{array}$ & $42.00-27.00$ & $26.00-11.00$ & $\leq 10.00$ & 0,30 & Superior \\
\hline $\begin{array}{l}\text { Responsiveness } \\
\text { Lead time pemenuhan pesanan } \\
\text { (hari) } \\
\text { Siklus pemenuhan pesanan (hari) }\end{array}$ & $7.00-6.00$ & $5.00-4.00$ & $\leq 3.00$ & 0,26 & $\begin{array}{l}\text { Superior } \\
\text { Superior }\end{array}$ \\
\hline \multicolumn{6}{|c|}{ Kinerja Internal } \\
\hline $\begin{array}{l}\text { Asset } \\
\text { Cash to cash cycle time (hari) } \\
\text { Persediaan harian (hari) }\end{array}$ & $\begin{array}{l}45.00-34.00 \\
27.00-14.00\end{array}$ & $\begin{array}{c}33.00-21.00 \\
13.00-0.01\end{array}$ & $\begin{array}{l}\geq 20.00 \\
=0.00\end{array}$ & $\begin{array}{c}9,42 \\
0,31\end{array}$ & $\begin{array}{c}\text { Superior } \\
\text { Advantage }\end{array}$ \\
\hline
\end{tabular}

Atribut reliability dapat menunjukan kemampuan petani mitra dalam melakukan pekerjaan sesuai dengan yang diharapkan, berdasarkan ketepatan waktu, kualitas yang sesuai dan jumlah yang tetap. Tabel 2 menjelaskan hasil pengukuran kinerja petani mitra Al-Ittifaq pada kinerja pengiriman dan pemenuhan pesanan masing-masing sebesar sebesar 95.84\% dan 98.35\%. Artinya, kinerja petani mitra dalam pengiriman dan pemenuhan pesanan memiliki kinerja terbaik dengan berada pada posisi superior, sehingga sangat perlu dipertahankan. Kinerja petani mitra terhadap kesesuaian standar produk yang diinginkan konsumen memperoleh nilai 89.80, sehingga ada pada posisi advantage. Terlihat masih adanya petani yang memasok produk yang tidak sesuai dengan standar ketetapan perusahaan. Menandakan masih dibutuhkannya perbaikan untuk meningkatkan atribut kinerja reliability pada petani mitra. Kegiatan yang diukur dalam atribut ini adalah sudah sejauh mana kemampuan petani mitra Al-Ittifaq dalam pengiriman pesanan, kemampuan dalam jumlah produk yang dikirimkan sudah sesuai pesanan serta kesesuaian standar produk dengan apa yang diharapkan konsumen (Pujawan dan Mahendrawati 2017).

Pengukuran kinerja rantai pasok petani mitra Al-Ittifaq pada atribut agility merupakan waktu yang dibutuhkan petani dalam merespon ketika ada perubahan pesanan yang harus dipenuhinya. Hasil perhitungan menunjukan nilai rata-rata petani sebesar 0.3 hari (7.2 jam) yang berada pada posisi masih di bawah 10 hari. Artinya kinerja petani dalam siklus pemenuhan pesanan sudah termasuk dalam kinerja terbaik atau sudah mencapai posisi superior. Semakin kecil nilai atribut agility, maka semakin baik capaian kinerjanya (Setiawan et al. 2011).

Nilai kinerja petani pada atribut responsiveness yang merupakan kecepatan petani dalam melaksanakan pekerjaannya, yang diukur melalui lead time pemenuhan pesanan dan siklus pemenuhan pesanan. Memperoleh nilai masing-masing sebesar 0.26 hari dan 0.325 hari sehingga berada pada posisi superior. Artinya, kedua kemampuan tersebut sudah mencapai posisi kinerja terbaiknya, maka diharapkan dapat mempertahankan kegiatannya. Sejalan dengan penelitian Setiawan (2011) menyatakan bahwa semakin kecil nilai lead time nya, maka semakin baik kinerja rantai pasoknya. Guritno et al. (2015), menjelaskan waktu tunggu pemenuhan pesanan pada sebuah rantai pasok dipengaruhi oleh berbagai faktor yang tidak terduga, sehingga sulit untuk dipastikan waktu selesainya.

\section{Kinerja Internal}


Pengukuran indikator internal rantai pasok petani mitra Al-Ittifaq pada penelitian kali ini diukur menggunakan atribut asset. Atribut asset merupakan kemampuan untuk memanfaatkan aset secara produktif. Tabel 2 menunjukkan bahwa kemampuan petani dalam mengubah persediaan/produk menjadi uang tunai telah mencapai kinerja terbaik (suprior), karena nilai cash to cash cycle time hanya sebesar 9.42 hari (10 hari) kurang dari 20 hari (bencmark superior). Semakin cepat waktu yang dibutuhkan untuk proses membayar dan menerima pembayaran produk, semakin baik rantai pasok perusahaan tersebut (Sutawijaya dan Marlapa 2016).

Terkadang petani melakukan penyimpanan produk karena mengalami kelebihan jumlah panen, sehingga perusahaan tidak mampu menyerapnya. Kelebihan jumlah panen tersebut biasanya disalurkan ke pasar tradisional. Penilaian kinerja persediaan harian petani mitra sebesar 0.31 hari, menempati posisi advantage, maka masih dibutuhkan peningkatan kinerja. Penilaian kinerja persediaan ini digunakan untuk mengetahui sampai mana kemampuan integrasi dengan perusahaan untuk mengelola persediaan yang mencakup siklus persediaan, efisiensi kapasitas, dan pengurangan biaya persediaan pada suatu jaringan rantai pasok (Yaqoub 2012).

\section{Kinerja Petani Mitra menurut Komoditas}

Kinerja rantai pasok berikutnya dilihat dari kelompok petani sesuai dengan komoditas yang diproduksinya. Setiap komoditas tentu memiliki karakteristik dan penanganan yang berbeda, membuat berbagai perlakuan pada rantai pasok setiap petani tidak sama. Berikut adalah indikator eksternal dalam penilaian kinerja petani menurut komoditas dalam kerangka SCOR, dapat dilihat pada Tabel 3.

Tabel 3. Hasil pengukuran kinerja petani menurut komoditas sayuran

\begin{tabular}{|c|c|c|c|c|c|}
\hline \multirow{3}{*}{ Atribut dan Indikator SCOR } & \multicolumn{2}{|c|}{ Bencmarking } & \multicolumn{3}{|c|}{ Rata-rata Kinerja } \\
\hline & \multirow{2}{*}{\multicolumn{2}{|c|}{$\begin{array}{l}\text { Advantage Superior } \\
\text { Kinerja Eksternal }\end{array}$}} & \multirow[t]{2}{*}{ Wortel } & \multirow[t]{2}{*}{$\begin{array}{c}\text { Daun } \\
\text { bawang }\end{array}$} & \multirow[t]{2}{*}{ Seledri } \\
\hline & & & & & \\
\hline $\begin{array}{l}\text { Reliability } \\
\text { Kinerja Pengiriman (\%) } \\
\text { Pemenuhan Pesanan (\%) } \\
\text { Kesesuaian dengan Standar (\%) }\end{array}$ & $\begin{array}{l}90.00-94.00 \\
96.00-97.00 \\
85.00-89.00\end{array}$ & $\begin{array}{l}\geq 95.00 \\
\geq 98.00 \\
\geq 90.00\end{array}$ & $\begin{array}{l}96,615 \\
98,85 \\
89,73\end{array}$ & $\begin{array}{l}95,28 \\
95,72 \\
91,42\end{array}$ & $\begin{array}{l}95,612 \\
98,46 \\
86,96\end{array}$ \\
\hline $\begin{array}{l}\text { Agility } \\
\text { Fleksibilitas (hari) }\end{array}$ & $26.00-11.00$ & $\leq 10.00$ & 0,383 & 0,275 & 0,25 \\
\hline $\begin{array}{l}\text { Responsiveness } \\
\text { Lead time pemenuhan pesanan (hari) } \\
\text { Siklus pemenuhan pesanan (hari) }\end{array}$ & $5.00-4.00$ & $\begin{array}{l}\leq 3.00 \\
\leq 4.00\end{array}$ & $\begin{array}{l}0,30 \\
0,575\end{array}$ & 0,67 & $\begin{array}{l}0,25 \\
0,50\end{array}$ \\
\hline \multicolumn{6}{|c|}{ Kinerja Internal } \\
\hline $\begin{array}{l}\text { Asset } \\
\text { Cash to cash cycle time (hari) } \\
\text { Persediaan harian (hari) }\end{array}$ & $\begin{array}{r}33.00-21.00 \\
13.00-0.01\end{array}$ & $\begin{array}{r}\geq 20.00 \\
=0.00\end{array}$ & $\begin{array}{c}12,50 \\
0,61\end{array}$ & $\begin{array}{c}7,25 \\
0,175\end{array}$ & $\begin{array}{l}8,50 \\
0,16\end{array}$ \\
\hline $\begin{array}{l}\text { Kinerja Eksternal } \\
\quad \text { Pengukuran indikator ekstern } \\
\text { pasok pada petani mitra Al-Ittifaq } \\
\text { komoditas pada penelitian ini diukur }\end{array}$ & $\begin{array}{l}1 \text { rantai } \\
\text { nenurut }\end{array}$ & $\begin{array}{l}\quad \text { meng } \\
\text { sponsivenes } \\
\text { apat men } \\
\text { alam mem } \\
\text { ermintaan }\end{array}$ & $\begin{array}{l}\text { sunakan } \\
\text { s, dan a } \\
\text { unjukkar } \\
\text { enuhi p } \\
\text { konsume }\end{array}$ & $\begin{array}{l}\text { atribut } \\
\text { ity. Atribu } \\
\text { kemampu } \\
\text { anan sesu } \\
\text { baik dari }\end{array}$ & $\begin{array}{r}\text { reliability, } \\
\text { reliability } \\
\text { n petani } \\
\text { i dengan } \\
\text { egi waktu }\end{array}$ \\
\hline
\end{tabular}


kuantitas pesanan, dan kualitas pada setiap kelompok komoditas.

Berdasarkan Tabel 3, pengukuran ratarata kinerja pengiriman dan pemenuhan pesanan, paling tinggi dicapai oleh petani dengan komoditas wortel yaitu $96.615 \%$ dan $96.85 \%$. Petani dengan komoditas wortel menempati posisi tertinggi dibandingkan dengan komoditas seledri dan daun bawang. Terjadi karenakan untuk komoditas sayuran daun-daunan memerlukan perlakuan yang lebih banyak oleh petani. Setelah di panen lalu dibersihkan, membutuhkan waktu tambahan untuk melakukan pengemasan dan pemilihan produk yang sesuai dengan standar permintaan konsumen. Wortel hanya perlu membersihkan tanpa pengemasan, karena grading dan pengemasan dilakukan oleh bagian packing di gudang Al-Ittifaq, sehingga pada pengiriman kebih cepat. Wortel juga merupakan salah satu komoditas unggulan paling utama bagi Al-Ittifaq karena memiliki permintaan terbanyak, maka dari itu banyak diproduksi oleh petani mitra AlIttifaq. Dibutuhkan ketersediaan wortel di Al-Ittifaq cukup untuk memenuhi kebutuhan ritel. Besar Nilai rata-rata kesesuaian standar rantai pasok paling tinggi dicapai oleh petani dengan komoditas daun bawang yaitu $91.42 \%$. Karena komoditas daun bawang sudah dilakukan pengemasan dari petani, sehingga sampai pada gudang Al-Ittifaq sudah dalam keadaan siap untuk di salurkan tinggal penambahan label saja.

Atribut agility pada kinerja rantai pasok petani mitra menurut komoditas, mencerminkan kemampuan petani di setiap komoditas dalam merespon perubahan pesanan. Atribut agility pada penelitian diukur menggunakan satuan waktu dengan satuan hari. Kinerja setiap petani mitra pada setiap komoditas sudah mencapai posisi terbaik (superior). Nilai kinerja tertinggi adalah wortel, dengan perolehan nilai ratarata 0,383 hari. Artinya, komoditas wortel paling cepat dalam merespon perubahan pesanan memerlukan waktu selama 9.2 jam untuk merespon bila adanya perubahan pesanan. Hal ini dikarenakan karakteristik wortel yang lebih tahan lama dibandingkan daun bawang dan seledri, maka pemenuhan perubahan pesanan bisa dipenuhi dari penyimpanan hasil panen hari sebelumnya.

Pengukuran kinerja petani mitra berdasarkan komoditas menggunakan atribut responsiveness pada masing-masing komoditas sudah mencapai kinerja terbaik (superior). Artinya, kinerja kecepatan dalam melaksanakan pekerjaan yang dilakukan petani mitra pada setiap komoditas sudah dilakukan dengan baik sesuai target. Nilai tertinggi pada matriks lead time pemenuhan pesanan dengan nilai rata-rata 0.3 hari $(7.2$ jam) adalah petani dengan komoditas seledri. Penanaman seledri dilakukan pada lahan yang paling dekat dengan rumah petani, sehingga tidak terlalu membutuhkan waktu banyak untuk melakukan pemanenan. Matriks siklus pemenuhan pesanan tercepat adalah petani dengan komoditas daun bawang yaitu 0.575 hari (13.8 jam). Nilai pada pengukuran responsiveness itu kecil, Karena semakin kecil nilai kinerjanya dipastikan semakin baik capaian kinerja rantai pasoknya (Setiawan 2011).

\section{Kinerja Internal}

Indikator internal rantai pasok sayuran petani mitra menurut komoditas pada penelitian ini diukur melalui atribut asset yang di identifikasi menggunakan dua matrik yaitu cash to cash cycle time dan persediaan harian. Tabel 3 menunjukkan bahwa semua petani menurut komoditas dalam memperoleh pembayaran sudah mencapai kerja terbaiknya atau berada pada posisi superior. Terjadi karena memiliki nilai rata-rata cash to cash cycle time atau pembayaran atas produk yang sudah disalurkan kurang dari 20 hari. Nilai rata-rata cash to cash cycle time paling tinggi adalah komoditas daun bawang. Terjadi karena petani pemasok daun bawang tidak melakukan persediaan harian, sehingga meminta pembayaran produk yang sudah dikirim lebih cepat untuk petani dapat melakukan penanaman lagi. Sejalan dengan penelitian Yolandika (2016) cash to cash cycle time ini dilakukan untuk melihat perputaran 
uang dari mulai penerimaan pembayaran dari ritel dan di bayarkan kepada petani yang dinyatakan dalam satuan hari, semakin rendahnya nilai metrik ini semakin baik

Perhitungan nilai kinerja persediaan harian menunjukkan bahwa semua komoditas hanya berada pada posisi advantage. Setelah panen, para petani mitra menjual hasil panennya langsung kepada perusahaan. Stok tidak dengan sengaja dilakukan, hal ini dikarenakan petani sering mengalami kelebihan pemanenan dari total pesanan. Apabila ada kelebihan panen yang jumlahnya cukup banyak, biasanya petani melaporkan kepada perusahaan untuk di jual ke pasar tradisional. Adapun nilai rata-rata persediaan harian yang rendah adalah petani daun bawang sebesar 0,18 hari (3.54 jam) dan seledri sebesar 0,175 hari (4.2 jam). Penyimpanan dengan nilai persentase yang kecil pada umumnya di alami oleh tanaman sayur hijau, yang di antara ke tiga sayuran tersebut adalah daun bawang dan seledri. Hal ini terjadi dikarenakan karakteristik sayuran hijau yang mudah layu dan kualitas kesegaran mudah turun. Petani selalu berusaha menghindari penyimpanan daun bawang, karena risiko rusaknya sangat tinggi. Sejalan dengan penelitian Yolandika (2016), petani mitra langsung menjual semua hasil panennya kepada perusahaan, selain untuk memberikan kualitas yang baik juga mengurangi biaya penyimpanan.

\section{Kinerja Rantai Pasok Al-Ittifaq}

Pengukuran kinerja merupakan salah satu bentuk peninjauan sebagai evaluasi dari seluruh proses dalam rantai pasok. Kinerja rantai pasok yang diukur selama satu musim tanam (Oktober sampai Desember 2018). Pengukuran capaian kinerja rantai pasok bisa diukur kurun waktu tiga hingga enam bulan bahkan setahun (Francis et al. 2008).

Tabel 4. Perbandingan nilai rata-rata kinerja rantai pasok pada Al-Ittifaq

\begin{tabular}{|c|c|c|c|c|c|}
\hline \multirow{2}{*}{ Atribut dan Indikator SCOR } & \multicolumn{3}{|c|}{ Bencmarking } & \multirow{2}{*}{ Rata-rata } & \multirow{2}{*}{ Hasil } \\
\hline & Parity & Advantage & Superior & & \\
\hline \multicolumn{6}{|c|}{ Kinerja Eksternal } \\
\hline \multicolumn{6}{|l|}{ Reliability } \\
\hline Kinerja Pengiriman (\%) & $85.00-89.00$ & $90.00-94.00$ & $\geq 95.00$ & 95,70 & Superior \\
\hline Pemenuhan Pesanan (\%) & $94.00-95.00$ & $96.00-97.00$ & $\geq 98.00$ & 98,30 & Superior \\
\hline Kesesuaian dengan Standar (\%) & $80.00-84.00$ & $85.00-89.00$ & $\geq 90.00$ & 86,50 & Advantage \\
\hline Agility & & & & & \\
\hline Fleksibilitas (hari) & $42.00-27.00$ & $26.00-11.00$ & $\leq 10.00$ & 0,31 & Superior \\
\hline $\begin{array}{l}\text { Responsiveness } \\
\text { Lead time pemenuhan pesanan } \\
\text { (hari) }\end{array}$ & $7.00-6.00$ & $5.00-4.00$ & $\leq 3.00$ & 0,83 & Superior \\
\hline $\begin{array}{l}\text { Siklus pemenuhan pesanan } \\
\text { (hari) }\end{array}$ & $8.00-7.00$ & $6.00-5.00$ & $\leq 4.00$ & 0,98 & Superior \\
\hline \multicolumn{6}{|c|}{ Kinerja Internal } \\
\hline Asset & & & & & \\
\hline $\begin{array}{l}\text { Cash to cash cycle time (hari) } \\
\text { Persediaan harian (hari) }\end{array}$ & $\begin{array}{l}45.00-34.00 \\
27.00-14.00\end{array}$ & $\begin{array}{c}33.00-21.00 \\
13.00-0.01\end{array}$ & $\begin{array}{r}\geq 20.00 \\
=0.00\end{array}$ & $\begin{array}{r}15,00 \\
0,17\end{array}$ & $\begin{array}{l}\text { Superior } \\
\text { Advantege }\end{array}$ \\
\hline
\end{tabular}

Penelitian ini mengukuran kinerja rantai pasok Al-Ittifaq berdasarkan matrik SCOR, yang dibagi menjadi dua jenis kinerja yaitu kinerja eksternal dan internal. Kinerja eksternal diukur dengan atribut responsiveness, agility, dan reliability, sedangkan kinerja internal dilihat berdasarkan atribut asset. Manajer membutuhkan sebuah pendekatan untuk evaluasi rantai pasok, yang mampu membandingkan kinerja dari berbagai perspektif organisasi, sebagaimana yang disarankan oleh stakeholder yang berbeda untuk memaksimalkan kinerjanya (Dissanayake dan Cross 2018). Nilai rata-rata 
atribut kinerja rantai pasok sayuran pada AlIttifaq disajikan pada Tabel 4.

\section{Kinerja Eksternal}

Kinerja eksternal merupakan kinerja suatu anggota rantai pasok yang melibatkan atau berhubungan dengan pihak luar dalam upaya pemenuhan kebutuhan pencapaian tujuannya. Enam matrik yang digunakan dalam mengukur kinerja rantai pasok yaitu pengiriman, pemenuhan pesanan, kesesuaian standar, fleksibilitas, lead time pemenuhan pesanan dan satu periode pemenuhan pesanan (Bolstorff dan Rosenbaum 2011).

\section{Kinerja Pengiriman}

Pengukuran kinerja pengiriman merupakan atribut yang menunjukan kemampuan perusahaan dalam memenuhi permintaan dengan baik berupa ketepatan waktu sesuai dengan batasan tanggal beserta waktu yang diinginkan oleh konsumen tanpa ada kerusakan. Tabel 4 menunjukan bahwa nilai kinerja pengiriman Al-Ittifaq sebesar $95.70 \%$ yang sudah mencapai kinerja terbaik (superior) pada foodSCOR card. Menandakan kinerja Al-Ittifaq telah menjalankan aktivitas terbaiknya dalam kemampuan pengiriman produk dengan utuh dan akhurat tanpa ada kerusakan pengiriman sebesar $95.70 \%$. Semakin mendekati $100 \%$ artinya capaian kinerja semakin membaik, dan ketika sudah mencapai $100 \%$ artinya pencapaian kinerja pengiriman sudah berada pada posisi kesempurnaan (Yolandika 2016). Hal tersebut dapat dikatakan Al-Ittifaq sudah mampu memenuhi permintaan ritel mitra dengan tepat waktu.

Pengiriman produk yang dilakukan setiap hari oleh bagian pengiriman produk. Kegiatan pengiriman dimulai berangkat dari gudang Al-Ittifaq pukul 03.00 WIB dan sampai dilokasi pertama tidak lebih dari pukul 08.00 WIB. Pemberian toleransi kedatangan produk ke ritel rata-rata maksimal pukul 10.00 WIB. Pengiriman sampai ke ritel di atas pukul $10.00 \mathrm{WIB}$, akan mendapat teguran bisa saja penolakan produk. Hal ini dapat berpengaruh terhadap kualitas produk. Ketepatan waktu dalam pengiriman akan mempengaruhi reliabilitas perusahaan. Pangsa pasar dan penjualan dapat ditingkatkan melalui strategi inovasi produk dan kedisplinan waktu pengiriman, sebab kedua tindakan tersebut mencerminkan kuatnya karakteristik responsivitas, fleksibilitas, dan reliabilitas perusahaan yang dapat memengaruhi peningkatan kepemilikan aset perusahaan (Mentzer et al. 2001).

\section{Pemenuhan Pesanan}

Kemampuan dalam memenuhi permintaan konsumen tanpa harus memerlukan waktu tunggu menjadi ukuran penilaian reliabilitas pada penelitian rantai pasok sayuran Al-Ittifaq. Semakin besar nilai rata-rata pemenuhan pesanan rantai pasok, maka semakin baik capaian kinerja rantai pasoknya (Sari 2017). Hasil perhitungan pada Tabel 4, menjelaskan rata-rata nilai kinerja pemenuhan pesanan sayuran Al-Ittifaq yaitu sebesar $98.30 \%$ berada pas posisi superior. Artinya Al-Ittifaq sudah dapat menghadirkan produk sayuran kepada konsumen tanpa memerlukan waktu banyak, untuk menunggu produknya tersedia sesuai dengan yang diinginkannya dengan kinerja terbaiknya. Kinerja terbaiknya ini harus terus di pertahankan, karena akan berpengaruh terhadap penilaian konsumen terhadap perusahaan. Faktor yang menyebabkan perusahaan tidak mampu memenuhi permintaan ritel adalah keadaan alam sehingga menyebabkan kegagalan panen, banyaknya produk yang di tolak konsumen karena tidak sesuai, dan petani yang tidak memberikan informasi apabila tidak dapat memenuhi pesanan (Apriani et al. 2018). Posisi kinerja Al-ittifaq berada pada kinerja terbaik, maka sudah mampu dalam mengintegrasikan faktor-faktir di atas.

\section{Kesesuaian dengan Standar}

Tujuan akhir dari rantai pasok sayuran Al-Ittifaq adalah kepuasan 
konsumen, dengan indikatornya adalah kesesuaian produk dengan standar yang diinginkan konsumen. Tabel 4 menunjukkan posisi kesesuaian produk dengan standar Al-Ittifaq hanya mencapai posisi advantage, dengan nilai $86.50 \%$. Kemampuan Al-Ittifaq dalam memenuhi standar konsumen masih perlu ditingkatkan agar mencapai posisi terbaik. Semakin dekat nilai rata-rata kesesuaian standar menuju angka 100\%, maka semakin baik kinerja rantai pasoknya (Sari 2015). Upaya yang dapat dilakukan AlIttifaq dalah memberikan pelatihan aktivitas pascapanen secara rutin kepada petani dan pendampingan kepada pegawai agar hanya menerima produk dari petani yang sesuai standar. Perusahaan juga bisa memberikan reward untuk memotivasi petani dalam memasok produk yang sesuai dengan standar ritel secara optimal.

\section{Fleksibilitas}

Kemampuan perusahaan dalam waktu menanggapi pesanan yang tidak terduga baik dalam penambahan pesanan maupun pengurangan jumlah disebut dengan fleksibilitas rantai pasok. AlIttifaq memberikan kebijakan kepada ritel untuk memberikan waktu perubahan pesanan maksimal pada pukul 14.00 WIB. Hal ini dilakukan karena pada pukul 16.00 WIB merupakan bawas petani mengantarkan sayuran pesanan kepada perusahaan. Menjelang sore petani sulit untuk memetik sayur ke lahan lagi, dan juga ada beberapa sayuran yang kualitasnya kurang baik apabila dipanen pada sore hari.

Tabel 4 menunjukan pengukuran nilai fleksibilitas rantai pasok sayuran di Al-Ittifaq adalah 0.31 hari (7.44 jam), sangat jauh dari capaian batas minimum pada posisi superior yaitu 10 hari. Hal ini dikarenakan perusahaan sudah membuat perjanjian dengan ritel untuk tidak mengubah pesanan setalah dikirim kepada perusahaan. Menjadikan performa kinerja flesksibilitas ini selalu dalam kondisi terbaik. Kinerja ini harus dapat dipertahankan agar konsumen dapat merasa puas dalam menjalin kerja sama. Hal ini juga sesuai dengan kriteria penilaian kinerja menurut Bolstroff dan Rosenbaum (2011), pada indikator siklus pemenuhan pesanan untuk mencapai kriteria baik pada kinerja suatu perusahaan $\leq 10$ hari. Artinya perusahaan mampu memenuhi pesanan tidak terduga dengan waktu yang tidak terlampau lama yaitu kurang dari 24 jam (1 hari).

\section{Lead Time Pemenuhan Pesanan.}

Pengukuran nilai lead time pemenuhan pesanan pada penelitian rantai pasok sayuran Al-Ittifaq, diketahui dari nilai rata-rata waktu yang dibutuhkan untuk memenuhi permintaan ritel dalam satu kali siklus pengiriman pasokan. 0.83 hari adalah waktu yang dibutuhkan Al-Ittifaq pada kinerja lead time pemenuhan pesanan. Waktu yang dibutuhkan Al-Ittifaq kurang dari tiga hari membuat konsumen ritel tidak menunggu lama, berarti sudah mencapai posisi superior pada foodSCOR card. Hal ini sejalan dengan penelitian Sutawijaya dan Marlapa (2016), semakin pendek waktu yang diperlukan maka semakin bagus supply chain perusahaan tersebut. Keberadaan pemasok pada atribut responsiveness menempati posisi yang sangat penting, karena keterlambatan pasokan dapat mengurangi penilaian terhadap perusahaan. Oleh karena itu, perusahaan harus mampu mengelola dan menjaga keharmonisan kerja sama dengan para pemasoknya (Manuj dan Sahin 2009).

\section{Siklus Pemenuhan Pesanan.}

Lamanya waktu yang dibutuhkan setiap satu kali periode pemenuhan pesanan diukur dengan atribut siklus pemenuhan pesanan. Rendahnya nilai siklus pemesanannya, semakin baik capaian kinerja rantai pasoknya (Setiawan et al. 2011; Yolandika 2016). Tabel 4 
menunjukkan besarnya nilai untuk kinerja siklus pemenuhan pesanan sayuran di AlIttifaq yaitu 0.98 hari (23.52 jam) masih kurang dari empat hari, artinya siklus pemenuhan pesanan Al-Ittifaq sudah mencapai posisi terbaik atau superior. Baik petani mitra, ritel, maupun perusahaan sudah memahami pola order yang setiap hari dilakukan, karena kerja sama yang terjalin sudah cukup lama. Hal ini memudahkan setiap anggota rantai pasok dalam melakukan order atau pesanan. Perhitungan siklus pemenuhan pesanan dilakukan dengan menjumlahkan beberapa variabel waktu yaitu waktu perencanaan, waktu sortasi, waktu pengemasan, dan waktu pengiriman.

\section{Kinerja Internal}

Kinerja internal merupakan pengukuran aktivitas rantai pasok yang lebih banyak melibatkan sumber daya dari dalam perusahaan. Kinerja internal rantai pasok pada atribut asset dengan turunan pada foodSCOR card diukur melalui cash to cash time cycle dan persediaan harian. Atribut asset akan dihitung dengan dua pendekatan yaitu waktu antara pelaku rantai pasok membayar dan menerima pembayaran produk serta persediaan harian (Bolstorff dan Rosenbaum 2011).

\section{Cash to Cash Cycle Time.}

Atribut kinerja cash to cash cycle time berupa matrik yang menghitung kecepatan rantai pasok dalam mengubah persediaan menjadi uang. Berdasarkan Tabel 4, nilai rata-rata cash to cash cycle time Al-Ittifaq adalah 15 hari. Artinya, kemampuan Al-Ittifaq dalam memanfaatkan aset secara poduktif telah mencapai kinerja terbaik atau posisi superior karena masih kurang dari 20 hari. Terdapat beberapa perbedaan pembayaran dari setiap ritel, ada yang sudah melakukan pembayaran setelah 3 hari barang dikirim karena adanya kerja sama dengan Bank, ada yang 14 hari setelah barang diterima ritel dan ada juga yang 30 hari setelah barang sampai di ritel. Semakin singkat waktu yang digunakan untuk mengubah persediaan, semakin bagus pula pencapaian kinerja rantai pasoknya (Pujawan dan Mahendrawathi 2017).

Perusahaan selalu berusaha untuk memberikan waktu pembayaran paling cepat kepada petani, karenakan dapat berpengaruh terhadap kepercayaan dan loyalitas petani mitra terhadap perusahaan. Usaha Al-Ittifaq dalam meminta waktu pembayaran yang lebih cepat kepada ritel dengan melakukan berbagai perjanjian dan kerja sama dengan pihak lain seperti bank. Membuat petani mitra akan lebih bersemangat untuk terus melakukan budidaya dan karena petani memerlukan biaya untuk melakukan produksi.

\section{Persediaan Harian.}

Kinerja persediaan harian merupakan lamanya persediaan yang cukup untuk memenuhi kebutuhan jika tidak ada pasokan yang masuk. Tabel 4 menunjukkan nilai persediaan harian AlIttifaq adalah 0,17 berarti masih berada pada posisi advantage pada foodSCOR card. Pemilihan keputusan tersebut dilakukan Al-Ittifaq pada sayuran yang tidak mudah layu dengan volume sedikit, bertujuan untuk berjaga-jaga apabila terjadi kekurangan pasokan atau persediaan tersebut menjadi pengganti produk yang mengalami kerusakan.

Karakteristik sayuran yang mudah rusak dan juga permintaan dari konsumen yang menginginkan produk dalam keadaan segar, sehingga penyimpanan dapat menambah pengeluaran biaya penyimpanan. Menurut bencmark pada posisi superior, perusahaan sebaiknya tidak melakukan penyimpanan produk maupun perencanaan untuk melakukan persediaan (Bolstorff dan Rosenbaum 2011). Sesuai dengan penelitian Yolandika (2016) dan Srihartati (2004), tidak adaya 
penyimpanan persediaan sesuai dengan tujuan rantai pasok, untuk menghadirkan produk berada di tempat waktu yang tepat dalam memenuhi permintaan konsumen, serta memastikan persediaan tidak berlebih maupun kurang

\section{KESIMPULAN DAN SARAN}

\section{KESIMPULAN}

Berdasarkan uraian di atas maka kesimpulan dalam penelitian ini adalah sebagai berikut :

1. Secara keseluruhan kinerja rantai pasok sayuran pada Pondok Pesantren Al-Ittifaq di Kabupaten Bandung sudah pada keadaaan baik.

2. Indikator internal pada perusahaan, petani mitra secara individu dan petani mitra secara komoditas. Kinerja atribut responsiveness (lead time pemenuhan pesanan dan siklus pemenuhan pesanan) dan agility sudah berada pada posisi superior. Tetapi pada atribut reliability pada turunannya yaitu kinerja kesesuaian standar masih berada pada posisi advantage, sedangkan atribut kinerja pengiriman dan pemenuhan pesanan pada kondisi terbaik (superior).

3. Indikator eksternal pada perusahaan, petani mitra secara individu dan petani mitra secara komoditas, pada atribut asset dengan turunanya yaitu cash to cash cycle time berada pada kinerja terbaiknya (superior). Tetapi, pada kinerja persediaan harian hanya mencapai posisi advantage pada semua tingkatan. Kinerja tersebut masih membutuhkan perbaikan kinerja dengan tidak melakukan persediaan harian untuk mengurangi biaya penyimpanan dan selalu menghadirkan sayuran segar.

\section{SARAN}

Adapun saran yang dapat diberikan antara lain:
1. Perusahaan melakukan peramalan pesanan yang akan diterima dan mempertimbangkan perhitungan pasokan yang akan mengalami return oleh ritel, sehingga kinerja perusahaan dalam kesesuaian pesanan dapat dilaksanakan dengan sangat baik.

2. Perusahaan terus memberikan pendampingan dan pelatihan pascapanen kepada petani mitra serta pegawai perusahaan, untuk meningkatkan performa perusahaan

3. Petani dalam penanganan pascapanen khususnya komoditas sayuran hijau lebih cermat dalam proses pengemasan, untuk mengurangi kerusakan produk sehingga produk dapat sampai konsumen dalam keadaan terbaiknya.

4. Mengurangi penyimpanan produk untuk mengurangi kemungkinan cacat produk sehingga selalu menghadirkan sayuran dalam keadaan segar.

\section{DAFTAR PUSTAKA}

Apriani D., 2018, Kinerja Rantai Pasok Sayuran Organik di PT SFO Kecamatan Cipanas Kabupaten Cianjur, Tesis, Program Magister Agribisnis, Institut Pertanian Bogor.

Apriani D., Nurmalina R., Burhanuddin, 2018, Evaluasi Rantai Pasok Sayuran Organik dengan Pendekatan Supply Chaion Operation Reference (SCOR), Jurnal Ilmiah Manajemen, Vol VIII, No. 2, 312-335.

Aramyam L.H., Alfons G.F.M., Lansink O., Fack G.A.F., Vorst V.D., Kooten O.V., 2007, Performance Measurement in Agri-Food Supply Chains: a Case Study, Supply Chain Management: An International Journal. Vol 12, No.4. 304-315.

Bolstorff P., Rosenbaum R., 2011, Supply Chain Excellence: A Handbook for Dramatic Improvement Using the SCOR Model, New York (US), AMACOM. 
[BPS] Badan Pusat Statistik Jawa Barat, 2017, Jawa Barat Dalam Angka 2017, Jawa Barat (ID): BPS Provinsi. [Internet], [Diunduh pada 03 Oktober 2018], Tersedia pada: www.jabar.bps.go.id

[BPS] Badan Pusat Statistik, 2017, Konsumsi Buah dan Sayuran 2017, Jakarta (ID): Badan Pusat Statistik, [Internet], [Diunduh pada 03 Oktober 2018], Tersedia pada: www.bps.go.id.

Direktorat Jendral Hortikultura Departemen Pertanian, 2010, Statistik Produksi Holtikultura, Jakarta (ID): Kementrian Pertanian. [Internet], [Diunduh pada 03 Oktober 2018], Tersedia pada: www.hortikultura.pertanian.go.id.

Direktorat Jendral Hortikultura Departemen Pertanian, 2017, Konsumsi Sayuran Indonesia, Jakarta (ID): Kementrian Pertanian. [Internet], [Diunduh pada 03 Oktober 2018], Tersedia pada: www.hortikultura.pertanian.go.id.

Dissanayake C. K., Cross J. A., (2018), Systematic Mechanism for Identifying the Relative Impact of Supply Chain Performance Areas on the Overall Supply Chain Performance using SCOR Model and SEM, International Journal of Production Economics, Vol 201, 102-115.

Fauroni R. L., 2011, Model Pemberdayaan Ekonomi ala Pesantren Al-Ittifaq Rancabali Kab Bandung, Jurnal Penelitian Sosial Keagamaan, Vol 5, No.1, Juni 2011.

Francis JQ, Poirer CC, Swink ML. 2008. Diagnostics Greatness: Ten Traits of the Best Supply Chains. J.Ross Publishing. The USA.

Guritno A. D., Fujianti R., Kusumasari D., (2015), Assessment of the Supply Chain Factors and Classification of Inventory Management in Suppliers Level of Fresh Vegetables, Agriculture and Agricultural Science Procedia, Vol 3, 51-55.
Harrison A., Hoek V. R., (2008), Logistics Management and Strategy: Competing through the supply chain, Prentice Hall, England.

[Kementan] Kementerian Pertanian, 2016, Statistik Produksi Hortikultura Tahun 2016, Pusat Data dan Sistrm Informasi Pertanian. Jakarta (ID), [Internet], [Diunduh pada 03 Oktober 2018], Tersedia pada: www.pusdatin.setjen.pertanian.go.id.

[Kementan] Kementerian Pertanian, 2017, Statistik Konsumsi Pangan 2017, Jakarta (ID). Pusat Data dan Sistem Informasi Pertanian. [Internet], [Diunduh pada 03 Oktober 2018], Tersedia pada: www.pusdatin.setjen.pertanian.go.id

Manuj I., Sahin F., 2011, A Model of Supply Chain and Supply Chain Decisionmaking Complexity, International Journal of Physical Distribution and Logistics Management, Vol 41, No.5, 511-549.

Mentzer J.T., De W. W., Keebler J.S., Min S., Nix N.W., Smith C.D., Zacharia Z.G., 2001, Defining Supply Chain Management, Journal of Business Logistics, Vol 22, No. 2, 125.

Polindi M., 2019, Pengaruh Karakteristik Enterpreneur terhadap Minat Berwirausaha (Studi Empiris pada Santri di Pondok Pesantren Al-Ittifaq Ciwidey Bandung), Al-Intaj Jurnal Ekonomi dan Perbankan Sayariah. Vol 5, No.1, Maret 2019.

Pujawan I. N., 2005, Supply Chain Management, Surabaya (ID), Gundawidya.

Pujawan I. N., Mahendrawathi E., 2017, Supply Chain Management, Edisi ke 3, Penerbit Andi. Yogyakarta.

Sari P. N., 2015, Pengaruh Relationship Marketing Terhadap Kinerja Rantai Pasok Beras Organik Bersertifikat Di 
Kabupaten Bandung Melalui Integrasi, Tesis, Institut Pertanian Bogor.

Sari I. R. M, 2017, Rantai Pasok Sayuran di PT Bimandiri Agro Sedaya, [Tesis], Bogor (ID), IPB, Program Magister Agribisnis, Institut Pertanian Bogor.

[SCC] Supply Chain Council, 2008 Supply Chain Operations Reference Model, Version 9.0, ISBN 0-615-20259-4.

Setiawan A., Marimin, Arkeman Y., Udin F., 2011, Studi Peningkatan Kinerja Manajemen Rantai Pasok Sayuran Dataran Tinggi di Jawa Barat, Jurnal Aritech, Vol 31, No. 1, 60-70.

Setiawan S. A., 2011, Studi Peningkatan Kinerja Manajemen rantai pasok sayuran dataran tinggi terpilih di Jawa Barat, Disertasi, Doktoral, Teknologi Industri Pertanian, Institut Pertanian Bogor.

Srihartati. 2004. The Global Language of Bussiness. Management Supply Chain. Indonesian Journal of Computing and
Cybernetics Systems (IJCCS). Vol 1, No. 9, 50-52.

Sutawijaya A. H dan Marlapa E., 2016, Supply Chain Management: Analisis dan penerpan menggunakan Reference (SCOR) di PT Indoturbine, Jurnal Ilmiah Manajemen, Vol 8, No. 1, 121138.

Vorst Van Der J.G.A.J., 2005, Effective Food Supply Chain (Generating, Modeling and Evaluating Supply Chain Scenarios, Logistics, and Operations Research Group, Amsterdam (NLD). Wageningen University.

Yaqoub A M., 2012, Pengaruh mediasi kepercayaan pada hubungan antara kolaborasi supply chain dan kinerja operasi, Jurnal Manajemen dan Kewirausahaan, Vol 14, No. 2, 138-146.

Yolandika C., 2016, Analisis Supply Cahin Management Brokoli CV. Yan's Fruit and Vegetable di Kabupaten Bandung Barat, Tesis, Program Magister Agribisnis, Institut Pertanian Bogor. 